Print ISSN: 2288-4637 / Online ISSN 2288-4645

doi:10.13106/jafeb.2020.vol7.no12.1035

\title{
Factors Affecting the Work Motivation of the Construction Project Manager*
}

\author{
Phuong Thanh PHAN ${ }^{1}$, Cuong Phu PHAM${ }^{2}$, Nhu Thi Quynh TRAN³, Hang Thi Thu LE , $^{4}$ \\ Hanh Thi Hong NGUYEN ${ }^{5}$, Quyen Le Hoang Thuy To NGUYEN ${ }^{6}$
}

Received: August 27, 2020 Revised: November 02, 2020 Accepted: November 16, 2020

\begin{abstract}
Project manager plays a very important role in the success of any project. The primary duty of the project manager is to combine the outcomes or results of the various processes and activities of project management into a systematic project management strategy or plan for the project. In the construction industry, a lack of motivation is an urgent problem for many project managers in construction and engineering projects. Lack of motivation affects the quality and productivity of jobs, reducing profits and growth for companies, businesses, contractors or organizations that rely on human resources. The reasons for this lack of motivation are diverse ranging from salary to culture to life and working environment, among others. Through surveys and data analysis using Cronbach's Alpha reliability and EFA (Exploratory Factor Analysis), our research scaled the factors affecting work motivation of project managers in the construction industry in Vietnam. The research results identified six major groups of relevant factors including (i) salary and benefits, (ii) work environment, (iii) promotion opportunities, (iv) organizational culture, (v) interest in the job, and (vi) relationship with the organization. From there, this paper contributed useful information as well as measures for businesses, companies, contractors or organizations in the construction industry.
\end{abstract}

Keywords: Construction Management, Exploratory Factor Analysis, Human Resource Management, Motivation, Project Manager

JEL Classification Code: L74, M12, O15

\begin{abstract}
*Acknowledgements:
[1] This research is funded by Ho Chi Minh City Open University under the grant number E2020.07.1.

[2] We also would like to thank Mr. Duy Hoang Le, Construction Management Program, Department of Project Management, Ho Chi Minh City Open University, Vietnam for helping this research.

${ }^{1}$ First Author. Lecturer, Department of Project Management, Ho Chi Minh City Open University, Vietnam. Email: phuong.pthanh@ou.edu.vn ${ }^{2}$ Dean, Assistant Professor, Faculty of Transport and Economics, Campus in Ho Chi Minh City, University of Transport and Communications, Vietnam. Email: cuongpp-ph@utc.edu.vn

${ }^{3}$ Lecturer, Faculty of Economics and Construction Management, Mientrung University of Civil Engineering, Vietnam.

Email: Tranthiquynhnhu@muce.edu.vn

${ }^{4}$ Lecturer, Department of Construction Management, University of Architecture Ho Chi Minh City, Vietnam.

Email: hang.lethithu@uah.edu.vn

${ }^{5}$ Assistant Professor, Faculty of Accounting and Auditing, Ho Chi Minh City Open University, Vietnam. Email: hanh.nth@ou.edu.vn

${ }^{6}$ Corresponding Author. Assistant Professor, Deputy Director, Office of Cooperation and Research Management, Ho Chi Minh City Open University, Vietnam [Postal Address: 97, Vo Van Tan Street, District 3, Ho Chi Minh City, 724000, Vietnam]

Email: quyen.nlhtt@ou.edu.vn
\end{abstract}

(c) Copyright: The Author(s)

This is an Open Access article distributed under the terms of the Creative Commons Attribution Non-Commercial License (https://creativecommons.org/licenses/by-nc/4.0/) which permits unrestricted non-commercial use, distribution, and reproduction in any medium, provided the original work is properly cited.

\section{Introduction}

In Southeast Asia, Vietnam is one of the countries whose economy has prospered in recent years (Lee, 2019; Nguyen \& Bui, 2020; Nguyen \& Nguyen, 2020; Thong et al., 2020). The economic growth rate of Vietnam in 2019 is more than 7 percent. This is due to several ventures involving domestic, international and PPP investment (Do, Veerasak, Masamitsu, \& Phong, 2016; Nguyen, Likhitruangsilp, \& Onishi, 2020). Moreover, many investment projects in construction industry have been successfully implemented, contributing to this development (Nguyen, Le-Hoai, Tran, Dang, \& Nguyen, 2019; Nguyen \& Nguyen, 2020; Khoa, Nguyen, \& Nguyen, 2020). This success depends on the fundamental human philosophy of finding the right person in addition to modern and advanced technology (Vo, Nguyen, \& Le-Hoai, 2019). It is the most important thing for any organization to achieve the success of a project. Indeed, the project manager is an essential part of project-based organizations in real world (Fisher, 2011; Sadeghi, Mousakhani, Yazdani, \& Delavari, 2014). The project manager's primary responsibility is to integrate the results of the different project management processes and activities into a comprehensive project 
management plan for the project. Then, he or she organizes and leads the project team and manages the implementation of the identified project scope, schedule, quality and cost (Goodwin, 1993; Luong, Tran, \& Nguyen, 2018; Mohammadi, Sadi, Nateghi, Abdullah, \& Skitmore, 2014; Odusami, 2002). Besides, they also supervise and control the entire project, comparing the results of the implementation process with the requirements for the approved plan (Jazebi \& Rashidi, 2013; Torfi \& Rashidi, 2011; Zavadskas, Vainiūnas, Turskis, \& Tamošaitienè, 2012). Then, the project manager will promptly detect the coming problems to take appropriate corrective actions for making necessary changes in the project.

Project management organizations are aware of the importance of project managers or leaders, the human capital, as a leading source of capital (Anantatmula, 2010; Jaafar \& Othman, 2013; Jazebi \& Rashidi, 2013; Nguyen, Mai, \& Huynh, 2019; Nguyen \& Ngo, 2020). Whether the project has modern machines, good service quality, a solid infrastructure, but no project manager capable of effective work and commitment, then the project is not likely to succeed. Therefore, the problem that concerns organizations and construction organizations is how they can generate the greatest benefit at the least cost. So, they seek project managers who are the most effective, most dedicated, and enthusiastic, in general, and in their work. To do this thing, the factors that influence a project manager's motivation must be identified.

\section{Literature Review}

Dynamism stimulates internal factors, manifested through the effort, diligence, and enthusiasm towards work to achieve the highest efficiency. There are many definitions of "dynamics" around the world today. According to his theory of expectations, Vroom (1962) noted that people's behavior and motivations for work are not necessarily determined by reality, but rather by people's perceptions of the expectations for the future. Motivation is the degree to which a person wants to meet and select his or her conduct to be mounted (Dunn, 2001; Johari \& Jha, 2020; Mitchell, 1982). The motivation factor can be used to exert effort to achieve the highest goals of the organization, provided that the organization meets several individual needs. Motivation is the reason an individual works to satisfy a goal (Robbins, 1993; Ruble, Eisenberg, \& Higgins, 1994). It can be incentivized by a job, its salary, a promotion, the supervision and co-worker relationships, all of which can affect attitudes, behavior, and determine the level of passion, commitment, participation, concentration (Crossman \& Abou-Zaki, 2003). From the above concepts, we can understand that motivation is the factor that creates reasons for action, motivate people to work actively, efficiently, quality, adapt, and help them be the most creative as they can be.

Abraham Maslow was a famous twentieth-century American psychologist and scientist. He had formulated the theory of human needs, which was published in 1943 (Garske \& Arkes, 1982; Maslow, 2013). His theory clarified how human needs must be met in order for a person to lead a physically and psychologically healthy and productive life. The theory has five ranks and is arranged from low demand to high demand. Low-level demand is biological and safety needs, which include eating, sleeping, resting, living, and being safe. Without the satisfaction of these lower-order needs, no higher-order needs will arise. When low-order needs are satisfied and these needs are overpowered, human beings are motivated to attain higher level needs. High-level needs are social needs, need to be respected, need to be fulfilled that are those that are satisfied by the human factor after the low-order needs have been achieved. When people have met low-level needs, they will have sufficient food and health and, thus, will want to have social relationships, emotional relationships, and be recognized and respected by others through their accomplishments. This theory is the base for all of the other theories of motivation.

In addition, Frederick Herzberg introduced a two-factor theory of job satisfaction and motivation (Ann \& Blum, 2020; Herzberg, 2017; Maidani, 1991). He divided the factors that contribute to job satisfaction and dissatisfaction into two groups. Herzberg stated that the maintenance is not the driving factor and does not bring more enthusiasm. However, if they do not exist they will lead to dissatisfaction. Motivating factors drive employees to be more enthusiastic and diligent at work, but without those factors, they will still work normally. Vroom's Expectancy theory differed from Maslow and Herzberg in that it did not focus on needs, but on outcomes (Fernet, Senécal, Guay, Marsh, \& Dowson, 2008; Parijat \& Bagga, 2014). Maslow and Herzberg focused only on the relationship between the internal needs to produce results for internal needs, Vroom's Expectancy theory separated the effort made from motivation, dynamic and efficiency. Vroom argued that people's behavior and motivations are not necessarily determined by reality, but rather by people's perceptions of their expectations for the future. However, Vroom's theory has been often criticized, but it remains the most comprehensive explanation of motivation. It was built on the formula: Motivation = Attraction (reward) $\mathrm{x}$ Expectations (doing the job) x Means (beliefs).

On the other hand, Adams (1965) theory of equity argued that people want to be treated equally. Employees tend to gauge their equity by comparing their efforts, their returns, and their proportions to their peers: (Individual income/ Individual effort spent) vs. (Colleague income/ Colleague effort spent) and individual assessment with 
Phuong Thanh PHAN, Cuong Phu PHAM, Nhu Thi Quynh TRAN, Hang Thi Thu LE, Hanh Thi Hong NGUYEN,

colleagues. If the comparison is equal, individuals feel that they are being treated fairly, and thus, they maintain their motivation for work and increase their productivity (Folger, 1986). On the other hand, if the results of the comparison are not equitable and workers believe that they are the losers, these employees tend to decrease their working capacity and their performance will decrease. They then are likely to demand an increase in their salary and benefits, along with better working conditions.

Kovach (1987), in his publication, surveyed more than a thousand employees and managers about the factors that affect work motivation in different industries in the United States. The research results showed that ten factors affect the work motivation of workers including (i) interesting work, (ii) appreciation of the work performed, (iii) perception of personal role, (iv) job security, (v) salary level, (vi) career advancement development opportunities, (vii) working conditions, (viii) superiors' attachment to employees, (ix) criticism of skillful discipline, and (x) the willingness of superiors to help to solve personal problems. However, this research model was formed in the late 1980s, so it has several shortcomings, such as not including welfare and relationships with colleagues, that were identified later.

The purpose of Lindner (1998) was to describe the importance of several factors in employee motivation at Ohio State University's Piketon Research and Expansion Center and Enterprise Center. Twenty-five employees working at Piketon Research and Expansion Center and Business Center identified 10 elements for motivation: (i) guaranteed work; (ii) supervisor sympathy with personal issues; (iii) personal loyalty to employees; (iv) interesting job; (v) good working conditions; (vi) skillful discipline; (vii) good salary; (viii) promotion and development in the organization; (ix) feeling worked; and (x) appreciate the work done. This study asked survey participants to rate the importance of the factors that motivated their work from 1 - most important to 10 - least important. The results of this study showed an "interesting job" ranked first, followed by a "good salary." The lowest ranking factor was "empathy for personal matters."

Moreover, based on Herzberg's two-factor theory, Tan, Waheed, and Teck-Hong (2011) surveyed a sales staff in Malaysia and proposed a research model of factors affecting work motivation that included: (i) promotion; (ii) success; (iii) working conditions; (iv) fine job; (v) relationship with superiors; (vi) money; (vii) relationship with colleagues; (viii) company policy; (ix) career development; (x) recognition; and (xi) nature of work. The results of this research showed that the most critical driver was working conditions. The second most crucial factor was recognition, followed by company policy and financial issues. They concluded that maintenance factors (external factors) multiplied the motivating factors for salespeople. Kukanja (2013) evaluated the factors influencing the motivation of travel service workers in the coastal area of Piran in Slovenia. That study surveyed 191 employees who worked at restaurants, cafes, and bars and tested the following factors: (i) salary; (ii) career development; (iii) education; (iv) welfare; (v) working atmosphere; and (vi) working time. The research results revealed that the most important influence was salary, followed by social welfare and flexible working time. The least important factor was training.

Ali Shaemi Barzoki, Ali Attafar, and RezaJannati (2012) also applied Herzberg's two-factor theory in their study of 147 employees out of 640 employees at Golpayegan City Saipa Corporation. The factors identified by the researchers included: (i) company policy; (ii) occupational safety; (iii) relationship with colleagues; (iv) supervision and relationship with superiors; (v) working conditions; (v) personal life; and (vi) salary and bonus. The research showed that the salary and wage had the highest impact and the greatest influence on workers' motivation to work. The least influential impact was their personal life. Boeve (2007) conducted a study of factors affecting job satisfaction of the assistant doctor training faculty in US medical schools using Herzberg's two-factor theory. The job satisfaction factor was divided into two groups: (i) the internal group included the nature of work, training, and advancement opportunities; (ii) the group of external factors included salary, superiors' support, and relationships with colleagues. The factors that brought satisfaction and satisfaction to employees were also motivating (DeShields, Kara, \& Kaynak, 2005).

Brooks (2007) interviewed via questionnaire a survey of 181 people in various occupations across the United States. The results showed that the combination of two factors that set job goals and job satisfaction is the best way to predict employee's work motivation. Also, other factors that strongly influence employee satisfaction included work performance evaluation, training, superiors, and contribution to the organization. Kukanja (2013) studied factors influencing the motivation of tourism service workers in Slovenia's coastal area of Piran of 191 employees who worked in bars, restaurants, and cafes. They were salary, career development, training, social welfare, a happy working atmosphere, and flexible working time. The research results found that wages were the most important factor, followed by social complexity and flexible working hours. Training was rated as the least important.

\section{Research Methodology}

This research was carried out according to the following procedure: (i) review relevant on the factors influencing the work motivation of construction project managers, (ii) design questionnaires, (iii) undertake pilot study, (iv) use official questionnaire survey, and (v) data analysis using statistical methods. The questionnaire was designed with 
a 5 -level scale (from 1 disagree to 5 strongly agree). The questionnaire was used as a document to interview managers in construction projects. Interview data were entered into the SPSS software and filtered before data analysis. Descriptive analysis, average factors ranking, and EFA (Exploratory Factor Analysis) techniques were performed to find out the main factors that influence project managers' motivation in construction projects.

\section{Results and Discussion}

Data in analysis included 105 valid surveys. Information required of the respondents to the questionnaire included current position, work experience as shown in Table 1. The percentages of construction project managers in the groups of years of experience were most concentrated in the group of 5-10 years (44.8\%) and the lowest in the group was 15 years $(3.8 \%)$. The other two groups within the second and third position, having less than 5 years and 10-15 years, with $28.6 \%$ and $22.9 \%$, respectively. Regarding the current position, EM (Engineering Management) group is accounted for approximately $44.8 \%$, with the GM (General Management) group making up $55.2 \%$. The responsibility of functional departments was $38.1 \%$, the project group was $34.3 \%$, and the concurrently both groups was $27.6 \%$. In general, data contained characteristics concerning the construction industry and was suitable for analysis.

The scale reliability test was performed for groups of questions and the entire questionnaire (Table 2). Cronbach's Alpha coefficients for component groups including Sal (0.908), Wel (0.698), Env (0.662), Rel (0.849), Pro (0.836), Cul (0.878), and Amb (0.785), were all at a value less than 0.6 and matched.

Table 1: Sample characteristics

\begin{tabular}{|l|c|c|}
\hline Description & Frequency & Percent (\%) \\
\hline Experience & & \\
\hline$<5$ years & 30 & 28.6 \\
\hline 5 - 10 years & 47 & 44.8 \\
\hline 10 - 15 years & 24 & 22.9 \\
\hline$>15$ years & 4 & 3.8 \\
\hline Position & & \\
\hline Engineering management & 47 & 44.8 \\
\hline General management & 58 & 55.2 \\
\hline Responsibility & & \\
\hline Functional departments & 40 & 38.1 \\
\hline Projects & 36 & 34.3 \\
\hline Plurality & 29 & 27.6 \\
\hline Total & 105 & 100.0 \\
\hline
\end{tabular}

Cronbach's Alpha for the entire questionnaire included 30 items with a value of 0.888 , so the scale in this study was appropriate.

Factors affecting work motivation of project managers in construction industry in Vietnam were ranked by mean in Table 3. Ranked first was Well factor (mean = 3.97) "get additional support for the public holidays." Wel4 factor was mean $=3.93$, which was "Get periodic health check-ups" ranked second. A third was Wel2, "Outstanding insurance" with a mean of 3.84. Fourth-ranked was Sal3 factor, "Salary paid on time," with a mean of 3.80, and the fifth rank was Cul2, "Good working manners" with a mean of 3.76. The group factors that most influence work motivation of project managers in construction industry were welfare, salary, and culture in the working environment.

An EFA analysis was done to find out the main reasons affecting the work motivation of project managers. The KMO test and Bartlett's tests also were done and the results showed that $\mathrm{KMO}=0.721$, and sig. value of Bartlett's test was $p<0.01$ (Table 4). Therefore, it was appropriate to conduct the EFA analysis.

There were 30 variables included in the EFA analysis. When the EFA process was done in a loop and items were excluded that did not meet the conditions. A total of 07 excluded variables including Wel2, Wel3, Wel4, Env5, Rel2, Re14, Amb2 after 6 EFA analysis processes. The analysis results showed that 06 component groups were established with 23 items, and the cumulative total variance explained of $72,030 \%$. Group 1 had a percentage of variance of $15,638 \%$ and it was the group with the largest variance explained concerning "wages and benefits". Group 2 contained cultural factors (accounted for a variance of $14,760 \%)$. The third group contained promotion factors that accounted for $13,657 \%$ of the variance. The remaining groups had lower variance rates of $11.2 \%, 9.54 \%$, and $7.24 \%$, belonging to the group of the working environment, passion, and relationship, respectively (Table 5). And the loading coefficients of component factors are shown in the Table 6 .

Table 2: Reliability statistics

\begin{tabular}{|l|c|c|}
\hline Name of groups & Cronbach's Alpha & N of Items \\
\hline Sal & 0.908 & 4 \\
\hline Wel & 0.698 & 5 \\
\hline Env & 0.662 & 5 \\
\hline Rel & 0.849 & 4 \\
\hline Pro & 0.836 & 4 \\
\hline Cul & 0.878 & 4 \\
\hline Amb & 0.785 & 4 \\
\hline All & 0.888 & 30 \\
\hline
\end{tabular}


Phuong Thanh PHAN, Cuong Phu PHAM, Nhu Thi Quynh TRAN, Hang Thi Thu LE, Hanh Thi Hong NGUYEN,

Table 3: Ranking of factors affecting work motivation of project managers in construction industry

\begin{tabular}{|c|c|c|c|c|}
\hline Code & Factors & Mean & SD & Rank \\
\hline Sal1 & I am well paid & 3.50 & 0.94 & 16 \\
\hline Sal2 & I am paid according to ability & 3.61 & 0.91 & 11 \\
\hline Sal3 & Salary paid on time & 3.80 & 1.04 & 4 \\
\hline Sal4 & There is a reward for my contribution. & 3.57 & 1.01 & 14 \\
\hline Wel1 & Get additional support costs for public holidays and New Year & 3.97 & 0.92 & 1 \\
\hline Wel2 & Outstanding insurance & 3.84 & 0.81 & 3 \\
\hline Wel3 & Timely attention to the life of the employee in difficulty & 3.49 & 0.83 & 17 \\
\hline Wel4 & Get periodic health check-ups & 3.93 & 0.85 & 2 \\
\hline Wel5 & Daily allowance meals & 3.12 & 1.23 & 29 \\
\hline Env1 & The place I work is perfect & 3.59 & 0.96 & 13 \\
\hline Env2 & The atmosphere where I work is fresh. & 3.41 & 0.93 & 23 \\
\hline Env3 & Full work support equipment & 3.64 & 0.92 & 7 \\
\hline Env4 & The place to work is very convenient & 3.48 & 1.02 & 18 \\
\hline Env5 & Suitable light, smoke, dust, temperature & 2.94 & 1.08 & 30 \\
\hline Rel1 & My colleagues are willing to help with work & 3.72 & 0.97 & 6 \\
\hline Rel2 & My colleagues are comfortable and easy to get along with & 3.62 & 0.94 & 10 \\
\hline Rel3 & Everyone always coordinates well to get the job done & 3.62 & 1.02 & 9 \\
\hline Rel4 & The superiors are always smiling, friendly, and supportive to the staff & 3.63 & 0.98 & 8 \\
\hline Pro1 & Enterprises always pay attention to staff training & 3.60 & 0.92 & 12 \\
\hline Pro2 & Known requirements for promotion & 3.52 & 1.08 & 15 \\
\hline Pro3 & The training program was right for me & 3.45 & 1.01 & 19 \\
\hline Pro4 & Trained every month or year & 3.34 & 0.97 & 25 \\
\hline Cul1 & Everyone is always united and love each other & 3.44 & 1.02 & 22 \\
\hline Cul2 & Good working manners & 3.76 & 1.01 & 5 \\
\hline Cul3 & Little controversy occurs & 3.44 & 0.95 & 20 \\
\hline Cul4 & Appropriate rules & 3.32 & 1.05 & 26 \\
\hline Amb1 & The work is assigned correctly for the specialized field & 3.36 & 1.21 & 24 \\
\hline Amb2 & Work helps broaden knowledge & 3.44 & 1.14 & 20 \\
\hline Amb3 & Work has a special meaning & 3.29 & 1.15 & 28 \\
\hline Amb4 & Work brings emotions & 3.31 & 1.08 & 27 \\
\hline
\end{tabular}

Table 4: KMO and Bartlett's test results

\begin{tabular}{|l|l|c|}
\hline Kaiser-Meyer-Olkin Measure of Sampling Adequacy & 0.721 \\
\hline \multirow{3}{*}{ Bartlett's Test of Sphericity } & Approx. Chi-Square & 1460.869 \\
\cline { 2 - 3 } & df & 253 \\
\cline { 2 - 3 } & Sig. & .000 \\
\hline
\end{tabular}


Table 5: Total Variance Explained

\begin{tabular}{|c|c|c|c|c|c|c|c|c|c|}
\hline \multirow{2}{*}{ Component } & \multicolumn{4}{|c|}{ Initial Eigenvalues } & \multicolumn{2}{|c|}{$\begin{array}{l}\text { Extraction Sums of } \\
\text { Squared Loadings }\end{array}$} & \multicolumn{3}{|c|}{$\begin{array}{c}\text { Rotation Sums of Squared } \\
\text { Loadings }\end{array}$} \\
\hline & Total & $\begin{array}{c}\text { \% of } \\
\text { Variance }\end{array}$ & $\begin{array}{c}\text { Cumulative } \\
\%\end{array}$ & Total & $\begin{array}{c}\% \text { of } \\
\text { Variance }\end{array}$ & $\begin{array}{c}\text { Cumulative } \\
\%\end{array}$ & Total & $\begin{array}{c}\% \text { of } \\
\text { Variance }\end{array}$ & $\begin{array}{c}\text { Cumulative } \\
\%\end{array}$ \\
\hline 1 & 5.791 & 25.179 & 25.179 & 5.791 & 25.179 & 25.179 & 3.597 & 15.638 & 15.638 \\
\hline 2 & 3.372 & 14.663 & 39.842 & 3.372 & 14.663 & 39.842 & 3.395 & 14.760 & 30.398 \\
\hline 3 & 2.659 & 11.560 & 51.402 & 2.659 & 11.560 & 51.402 & 3.141 & 13.657 & 44.054 \\
\hline 4 & 1.831 & 7.960 & 59.362 & 1.831 & 7.960 & 59.362 & 2.576 & 11.200 & 55.254 \\
\hline 5 & 1.633 & 7.102 & 66.464 & 1.633 & 7.102 & 66.464 & 2.194 & 9.538 & 64.793 \\
\hline 6 & 1.280 & 5.567 & 72.030 & 1.280 & 5.567 & 72.030 & 1.665 & 7.238 & 72.030 \\
\hline 7 & .920 & 4.001 & 76.031 & & & & & & \\
\hline 8 & .802 & 3.488 & 79.520 & & & & & & \\
\hline 9 & .733 & 3.188 & 82.708 & & & & & & \\
\hline 10 & .596 & 2.591 & 85.299 & & & & & & \\
\hline 11 & .552 & 2.398 & 87.697 & & & & & & \\
\hline 12 & .459 & 1.994 & 89.692 & & & & & & \\
\hline 13 & .402 & 1.749 & 91.441 & & & & & & \\
\hline 14 & .338 & 1.471 & 92.911 & & & & & & \\
\hline 15 & .305 & 1.327 & 94.239 & & & & & & \\
\hline 16 & .258 & 1.124 & 95.362 & & & & & & \\
\hline 17 & .211 & .918 & 96.280 & & & & & & \\
\hline 18 & .200 & .869 & 97.149 & & & & & & \\
\hline 19 & .198 & .859 & 98.008 & & & & & & \\
\hline 20 & .145 & .630 & 98.638 & & & & & & \\
\hline 21 & .129 & .561 & 99.200 & & & & & & \\
\hline 22 & .102 & .445 & 99.645 & & & & & & \\
\hline 23 & .082 & .355 & 100.000 & & & & & & \\
\hline
\end{tabular}


Phuong Thanh PHAN, Cuong Phu PHAM, Nhu Thi Quynh TRAN, Hang Thi Thu LE, Hanh Thi Hong NGUYEN,

Table 6: Rotated Component Matrix

\begin{tabular}{|l|c|c|c|c|c|c|}
\hline & \multicolumn{5}{|c|}{ Component } \\
\hline & $\mathbf{1}$ & $\mathbf{2}$ & $\mathbf{3}$ & $\mathbf{4}$ & $\mathbf{5}$ & $\mathbf{6}$ \\
\hline Sal4 & .929 & & & & & \\
\hline Sal2 & .902 & & & & & \\
\hline Sal1 & .891 & & & & & \\
\hline Sal3 & .716 & & & & & \\
\hline Wel1 & .595 & & & & & \\
\hline Cul1 & & .842 & & & & \\
\hline Cul4 & & .827 & & & & \\
\hline Cul2 & & .823 & & & & \\
\hline Cul3 & & .808 & & & & \\
\hline Pro4 & & & .825 & & & \\
\hline Pro2 & & & .792 & & & \\
\hline Pro1 & & & .786 & & & \\
\hline Pro3 & & & .762 & & & \\
\hline Env1 & & & & .808 & & \\
\hline Env2 & & & & .741 & & \\
\hline Env3 & & & & .719 & & \\
\hline Env4 & & & & .672 & & \\
\hline Amb3 & & & & & .846 & \\
\hline Amb4 & & & & & .780 & \\
\hline Amb1 & & & & & .750 & \\
\hline Rel3 & & & & & & .700 \\
\hline Wel5 & & & & & & .688 \\
\hline Rel1 & & & & & & .671 \\
\hline
\end{tabular}

\section{Conclusions}

This paper presents the factors that influence the work motivation of project managers in construction projects. Through analysis of the collected data, the group of influential factors of work motivation of project managers in construction industry in Vietnam was determined. They are factors such as salary and benefits, work environment, promotion opportunities, organizational culture, interest in work, relationship with the organization. The five most important factors are evaluated in descending order below: (i) get additional support for the public holidays; periodic health examination; (iii) outstanding insurance; (iv) salary paid on time; and (v) good working manners. The results of this paper are given to be able to help businesses, organizations, contractors or construction project managers have an overview of the factors affecting the work motivation of project managers or staff. From there, giving the most suitable solutions to motivate their project manager or employees to work most effectively.

\section{References}

Adams, J. S. (1965). Inequity in social exchange. In: Advances in experimental social psychology (Vol. 2, pp. 267-299). Amsterdam, Netherlands: Elsevier.

Ali Shaemi Barzoki, Ali Attafar, \& Ali RezaJannati. (2012). An Analysis of Factors Affecting the Employees Motivation based on Herzberg's Hygiene Factors Theory. Australian Journal of Basic and Applied Sciences, 6(8), 115 -123.

Anantatmula, V. S. (2010). Project manager leadership role in improving project performance. Engineering Management Journal, 22(1), 13-22. https://doi.org/10.1080/10429247.2010 .11431849

Ann, S., \& Blum, S. C. (2020). Motivating senior employees in the hospitality industry. International Journal of Contemporary Hospitality Management. https://doi.org/10.1108/IJCHM-082018-0685

Boeve, W. D. (2007). A national study of job satisfaction factors among faculty in physician assistant education. Doctoral Dissertation, Eastern Michigan University.

Brooks, A. M. (2007). It's all about the motivation: Factors that influence employee motivation in organizations. Doctoral Dissertation, University of Tennessee, Knoxville. https://trace. tennessee.edu/cgi/viewcontent.cgi article $=5926 \&$ context $=$ utk_graddiss

Crossman,A., \&Abou-Zaki, B. (2003). Job satisfaction and employee performance of Lebanese banking staff. Journal of Managerial Psychology. https://doi.org/10.1108/02683940310473118

DeShields, O. W., Kara, A., \& Kaynak, E. (2005). Determinants of business student satisfaction and retention in higher education: Applying Herzberg's two-factor theory. International journal of educational management. https://doi. org/10.1108/09513540510582426

Do, T. S., Veerasak, L., Masamitsu, O., \& Phong, T. N. (2016). Different perceptions of concern factors for strategic investment of the private sector in public-private partnership transportation projects. ASEAN Engineering Journal, 5(2), 05-25.

Dunn, S. C. (2001). Motivation by project and functional managers in matrix organizations. Engineering Management Journal, 13(2), 3-10. https://doi.org/10.1080/10429247.2001.11415110

Fernet, C., Senécal, C., Guay, F., Marsh, H., \& Dowson, M. (2008). The work tasks motivation scale for teachers (WTMST). Journal of Career Assessment, 16(2), 256-279. https://doi. org/10.1177/1069072707305764

Fisher, E. (2011). What practitioners consider to be the skills and behaviours of an effective people project manager. International Journal of Project Management, 29(8), 994-1002. https://doi. org/10.1016/j.ijproman.2010.09.002

Folger, R. (1986). Rethinking equity theory. In: Justice in social relations (pp. 145-162). New York, NY: Springer.

Garske, J., \& Arkes, H. R. (1982). Psychological theories of motivation. Pacific Grove, CA: Brooks/Cole Publishing. 
Goodwin, R. (1993). Skills Required of Effective Project Managers. Journal of Management in Engineering, 9(3), 217-226. https:// doi.org/10.1061/(ASCE)9742-597X(1993)9:3(217)

Herzberg, F. (2017). Motivation to work. New York, NY: Routledge.

Hong Tan, T., Waheed, A., \& Teck-Hong, T. (2011). Herzberg's motivation-hygiene theory and job satisfaction in the Malaysian retail sector: The mediating effect of love of money Herzberg's motivation-hygiene and job satisfaction in the Malaysian retail sector: Mediating effect of love of money. Asian Academy of Management Journal, 16(1), 73-94.

Jaafar, M., \& Othman, N. L. (2013). Assessing the capability of women construction project managers based on liberal feminist theory. International Journal of Construction Management, 13(4), 35-52. https://doi.org/10.1080/1562359 9.2013.10878228

Jazebi, F., \& Rashidi, A. (2013). An automated procedure for selecting project managers in construction firms. Journal of Civil Engineering and Management, 19(1), 97-106. https://doi. org/10.3846/13923730.2012.738707

Johari, S., \& Jha, K. N. (2020). Impact of Work Motivation on Construction Labor Productivity. Journal of Management in Engineering, 36(5), 04020052. https://doi.org/10.1061/(ASCE) ME.1943-5479.0000824

Kenneth A.Kovach. (1987). What motivates employees? Workers and supervisors give different answers. Business Horizons, 30(5). https://doi.org/10.1016/0007-6813(87)90082-6

Kukanja, M. (2013). Influence of demographic characteristics on employee motivation in catering companies. Tourism and Hospitality Management, 19(1), 97-103.

Lee, J. W. (2019). Lagged effect of exports, industrialization and urbanization on carbon footprint in Southeast Asia. International Journal of Sustainable Development and World Ecology, 26(5), 398-405. https://doi.org/10.1080/13504509.20 19.1605425

Lindner, J. R. (1998). Understanding employee motivation. Journal of Extension, 36(3), 1-8.

Luong, D. L., Tran, D. H., \& Nguyen, P. T. (2018). Optimizing multi-mode time-cost-quality trade-off of construction project using opposition multiple objective difference evolution. International Journal of Construction Management, 01-13. https://doi.org/10.1080/15623599.2018.1526630

Maidani, E. A. (1991). Comparative study of Herzberg's two-factor theory of job satisfaction among public and private sectors. Public Personnel Management, 20(4), 441-448. https://doi. org/10.1177/009102609102000405

Maslow, A. H. (2013). A theory of human motivation. New York, NY: Simon and Schuster.

Mitchell, T. R. (1982). Motivation: New directions for theory, research, and practice. Academy of Management Review, 7(1), 80-88. https://www.jstor.org/stable/257251

Mohammadi, F., Sadi, M. K., Nateghi, F., Abdullah, A., \& Skitmore, M. (2014). A hybrid quality function deployment and cybernetic analytic network process model for project manager selection. Journal of Civil Engineering and Management, 20(6), 795-809. https://doi.org/10.3846/13923730.2014.945952

Nguyen, H. M., \& Bui, N. H. (2020b). Revisiting the relationship between energy consumption and economic growth nexus in Vietnam: New evidence by asymmetric ARDL cointegration. Applied Economics Letters, 1-7. https://doi.org/10.1080/13504 851.2020.1789543

Nguyen, H. M., Mai, L. T., \& Huynh, T. L. (2019). The role of transformational leadership toward work performance through intrinsic motivation: A study in the pharmaceutical field in vietnam. Journal of Asian Finance, Economics and Business, 6(4), 201-212. doi:10.13106/jafeb.2019.vol6.no4.201

Nguyen, H. M., \& Ngo, T. T. (2020). Psychological capital, organizational commitment and job performance: A case in Vietnam. Journal of Asian Finance, Economics and Business, 7(5), 269-278. https://doi.org/10.13106/jafeb.2020.vol7. no5.269

Nguyen, L. D., Le-Hoai, L., Tran, D. Q., Dang, C. N., \& Nguyen, C. V. (2019). Effect of project complexity on cost and schedule performance in transportation projects. Construction Management and Economics, 37(7), 384-399. https://doi.org/1 $0.1080 / 01446193.2018 .1532592$

Nguyen, P., \& Nguyen, P. (2020). Risk Management in Engineering and Construction: A Case Study in Design-Build Projects in Vietnam. Engineering, Technology \& Applied Science Research, 10(1), 5237-5241.

Nguyen, P. T., Likhitruangsilp, V., \& Onishi, M. (2020). Success factors for public-private partnership infrastructure projects in Vietnam. International Journal on Advanced Science, Engineering and Information Technology, 10(2), 858-865. https://doi.org/10.18517/ijaseit.10.2.5839

Nguyen, P. T., \& Nguyen, Q. L. H. T. T. (2020). Critical Factors Affecting Construction Price Index: An Integrated Fuzzy Logic and Analytical Hierarchy Process. Journal of Asian Finance, Economics and Business, 7(8), 197-204. https://doi. org/10.13106/jafeb.2020.vol7.no8.197

Odusami, K. (2002). Perceptions of Construction Professionals Concerning Important Skills of Effective Project Leaders. Journal of Management in Engineering, 18(2), 61-67. https:// doi.org/10.1061/(ASCE)0742-597X(2002)18:2(61)

Parijat, P., \& Bagga, S. (2014). Victor Vroom's expectancy theory of motivation: An evaluation. International Research Journal of Business and Management, 7(9), 1-8.

Robbins, S. P. (1993). Organizational Behavior: A Managerial and Organizational Perspective: Englewood Cliffs, NJ: PrenticeHall.

Ruble, D. N., Eisenberg, R., \& Higgins, E. T. (1994). Developmental changes in achievement evaluation: Motivational implications of self-other differences. Child Development, 65(4), 10951110. https://www.jstor.org/stable/1131307

Sadeghi, H., Mousakhani, M., Yazdani, M., \& Delavari, M. (2014). Evaluating Project Managers by an Interval Decision-Making 
Method Based on a New Project Manager Competency Model. Arabian Journal for Science and Engineering, 39(2), 14171430. https://doi.org/10.1007/s13369-013-0631-0

Thong, Q. V., Cuong, P. P., Thu, A. N., Phong, T. N., Phuong, T. P., \& Quyen, L. H. T. T. N. (2020). Factors Influencing Cost Overruns in Construction Projects of International Contractors in Vietnam. Journal of Asian Finance, Economics and Business, 7(9), 389-400. https://doi.org/10.13106/jafeb.2020. vol7.no9.389

Torfi, F., \& Rashidi, A. (2011). Selection of project managers in construction firms using analytic hierarchy process (ahp) and fuzzy topsis: A case study. Journal of Construction in Developing Countries.
Vo, K. D., Nguyen, P. T., \& Le-Hoai, L. (2019). The difference in personality traits of construction engineers in Vietnam using the KTS instrument. Suranaree Journal of Science and Technology, 26(2), 232-239.

Vo, K. D., Nguyen, P. T., \& Nguyen, Q. (2020). Disputes in Managing Projects: A Case Study of Construction Industry in Vietnam. Journal of Asian Finance, Economics and Business, 7(8), 635644. https://doi.org/10.13106/jafeb.2020.vol7.no8.635

Zavadskas, E. K., Vainiūnas, P., Turskis, Z., \& Tamošaitienè, J. (2012). Multiple criteria decision support system for assessment of projects managers in construction. International Journal of Information Technology \& Decision Making, 11(02), 501-520. https://doi.org/10.1142/S0219622012400135 